\title{
Welfare State in the Light of the Ongoing Changes in the European Labour Market
}

\author{
Magdalena Kotýnková
}

\begin{abstract}
During the second half of the $20^{\text {th }}$ century there have been significant changes in the structure and concept of the welfare state in Europe, mainly due to the changes in labour market and demographic changes. This was accompanied by a multiple increase in public expenditure in the social sector and the welfare state has found itself in a crisis since the $90 \mathrm{~s}$ of the last century. Given the fiscal unsustainability of the current social systems, measures and reforms addressing the fiscal crisis of the welfare state are being introduced. The current keynote is to narrow down the role of the state to the provider of basic social protection and encourage the citizens towards more responsible behaviour. The aim of this paper is to assess the dynamics of current social expenditure of the $\mathrm{EU}$ member countries in the light of the ongoing changes in the labour market and identify the fiscal trend. It emerged that a significant change affecting the need for the transformation of the welfare state is the increasing natural unemployment rate. People threatened by the unemployment, especially by the long term unemployment and job insecurity become dependant on social benefits and do not adequately contribute to the social system used to finance the benefits. The paper is mainly centred around the opinions of leading European experts on welfare states, EU strategic documents and Eurostat and OECD statistics.
\end{abstract}

Keywords - welfare state, social policy expenditure, labour market, population aging, social reform

\section{Introduction}

Since the past century, the European countries have gone through major social reforms. From the end of the $19^{\text {th }}$ century, Europe has been one of the most dynamically developing continents in terms of social risk protection. Step by step the European welfare state started to evolving. The objective of the welfare state and the reason for its establishment was to protect families and individuals against social risks in the society. Traditionally, this concerns adequate income to cover basic needs at the time of sickness, old age, unemployment etc. Besides these traditional social risks, new risks started being discussed in the end of the 70s associated with the onset of postindustrial era. The most significant problems appear to be changes in the labour market, demographic changes and, first and foremost, lack of funds to operate all types of the welfare state related with all other risks.

Authors Name: Magdalena Kotýnková

University Name: University of Economics Prague

Czech Republic

\section{Approaches to the Welfare State Definition}

Approaches to the welfare state definition differ amongst the authors. German economist and social scientist Manfred Spieker understands the welfare state as "a state endeavouring to provide its citizens with protection from direct risks originating from sickness, disability, old age and unemployment". In a broader sense of the word, a ,state endeavouring to provide not only social security but also social justice, social integration and social freedom" (Spieker, 1996).

British economist Nicolas Barr in his book Economics of the Welfare state explains the mission of the welfare state: "Social state exists to improve the welfare of people who are weak and vulnerable, by providing social benefits, and to those who are not weak and vulnerable it provides social and health insurance and organises school education"(Baar, 2004).

American social scientist Harold L. Wilensky defines the substance of welfare state as "a government-protected minimum level of income, subsistence, health, housing and education for each citizen as a political right, not as a charitable allowance" (Večeřa, 2001). This definition is related to the welfare state expenditure which include all government outlays on social matters, education, health, and expenditure on housing and social infrastructure (Kubátová, 2011).

Leading personalities in the process of the welfare state formation and development were Otto von Bismarck in Germany and Lord William Henry Beveridge, who established a comprehensive, well-functioning social security system in Great Britain and laid philosophical foundations of the welfare state as well as the term "welfare state" itself.

Over a hundred years, the welfare state went through several stages, starting from the first insurance company systems through the "golden era" of the 60s of the last century (hereinafter: "the 60s"), to the current welfare state crisis. Evolution of the social systems in the individual countries differed to a large extent with respect to the voluntariness, i.e. insurance cover obligation related to various losses. The oldest compulsory insurance concerned occupational accidents was introduced in several European countries before the end of the $19^{\text {th }}$ century. On the contrary, unemployment insurance was often voluntary and in most cases became compulsory after Word War I. Compared to the European countries it must be stressed that liberal countries such as the USA and Canada established and developed the welfare state with a delay of several decades (Večeřa, 2001). 
The period of social expansion (1962 - 1973), sometimes also called "the golden era of welfare state", is characterised by growing productivity and related rising standard of living of all social classes and high employment rate, in some Western countries up to almost full employment rate. Thanks to sufficient funds, the number of social benefits increased along with the amounts as well as the share of social expenses in the GDP (Smutek, 2005).

During the $70 \mathrm{~s}$ of the last century (hereinafter: "the 70 s"), the welfare states started gradually stagnating with the main reason being the oil crisis which brought about an economic crisis and major increase in the unemployment rate. While some countries reached up to $5 \%$ annual GDP increase in the previous decades, the economic growth in mid-70s slumped to negative figures. The GDP drop was followed by a major increase in unemployment rate and higher inflation rate. The governments came up against great pressures of rising social expenditure related mainly to unemployment and other benefits. Given the setup of the social systems in the past and the very limited possibilities of limiting some of the public expenditure, i.e. in health system, education, social services, the increasing public expenditure share was accompanied by public debt. As a result of these as well as other factors such as the commencing population changes and population aging, the welfare states started struggling with the crisis which principally persists to date. (Smutek, 2005)

Although there are common features in the evolution of the welfare state in the individual countries, for example the growing role of the state in social policy, rate of redistribution and provision of social services, there are also many differences between them. The scope of social services differs depending on the economic conditions of the state, traditions, values and historic development. Currently, there are several welfare state typologies. Danish social and political scientist Esping-Andersen divides welfare states according to the conception of solidarity amongst the citizens into three basic model: social - democratic, liberal and conservative - corporatist. British social scientist Titmuss divides the welfare state according to the criteria of solidarity into residual, institutional and performance types. Mishra's typology is based on the criteria of the rate of coordination of economic and social policy and distinguishes between two types of welfare state: integrated and desintegrated. (Musil, 1996) Another typology is specified by Czech social scientist Jan Keller, who divides welfare states into four groups: continental, Scandinavian, residual and rudimentary (Keller, 2009).

\section{The European Labour Market and its Changes}

The original welfare state was built on a wellfunctioning labor market, but new social risk emerged, which is unemployment, especially long-term unemployment. It can be said that the industrial era dominated in Europe since the second half of the 19th century ends today.

Since the end of the 70s, economic activity and consequently the labour market have been changed by progressive implementation of labour-saving technologies, information and telecommunication technologies and algorithms. The character of economic activity was changed and afterword contents and forms of work were changed as well. These changes were accompanied by growing uncertainty of labour market and the level of unemployment.

Unemployment and insecurity of the labour market started to grow at the 70s when labour-saving technologies appeared. These technologies weakened relations between economic growth and job creation. Owing to that, the world of work changed dramatically, free workforce started to pass from the industry to the service sector. Gradually the whole structure of the economy has changed, services are becoming dominant namely both in the share in GDP and in employment. With the time production of material property stopped being crucial for the economic growth, but production of knowledge and algorithms together with flows of information and their application have been becoming the most important. This caused a change in the relation between the capital and paid work.

If there had been a relation of mutual dependence between economic growth and volume and quality of workforce typical of the industrial era, in the post-industrial era the interconnection does not go anymore (Baumann, 1998). The factor of work was becoming marginal in relation to the economic growth. The relation between economic growth and labour was separated which can be proved with the fact that the economic growth during the last decades of the $20^{\text {th }}$ century started to be reached even when the number of vacancies stagnated or increased very slowly (European Commission, 1994). Similarly the International Organisation of Labour states that $1 \%$ economic growth encourages increase in new workplaces by $0.3 \%$ while the relation keeps weakening (ILO, 2013).

At the time, the economic theory accepted a conception of so called natural unemployment rate where unemployment was considered being a natural phenomenon. The conception of the natural unemployment rate supposes the existence of the lowest long-term sustainable unemployment rate corresponding with a potential product. There is the question of such unemployment rate which is typical of the economy at a certain stage of development. Efforts to reduce the natural rate by means of demand oriented economic policy of the government or the Central Bank will lead to the rise in inflation. Milton Friedman by the criticism of Philips curve, which comes from mutual dependence of unemployment and inflation (unemployment can be reduced despite higher inflation), stated that the dependence is true only for a short-term. In the long term, the Philips curve is stabilised at a level of natural unemployment_(Friedman, 1968).

But in the course of time it seems that the natural rate of unemployment keeps increasing which might be caused not only by labour-saving technologies, but also by the overall change in the type and organisation of labour (move from the importance of material production to nonmaterial one). It expels not only low-skilled workers, but also profession with higher qualification which is nowadays visible.

Together with changes in the character and contents of work, forms of work are changing as well. Since the 70s a pressure on the rise in flexibility of the labour market as a consequence of fast changing environment where innovation and rapid change of production programmes can be noticed. To enforce higher flexibility of the labour market, employers are motivated by competitive pressure and effort 
for the highest effectiveness of invested funds. Flexibility of the labour market means ability to adapt to changes in the commodity and services market, but its growth is often connected with the loss of employees' securities and the loss of stable work places. Currently, in the labour market we can see a decline in the importance of traditional occupational relations and an increase of diversities, individualization and uncertainty of work relations.

Unemployment and uncertainty in the labour market which have become a consequence of insufficient job creation have been increasing together with changes in the character of work in post-industrial societies. Rapidly applied scientific inventions and findings help labour-saving technologies enter the work process and replace manual workers. Information and communication technologies (hereinafter: "ICT") prefer processes aimed at the reshape of mass to work with information. ICT application brings automation of work activities, improved management, acceleration of internal and external communication etc.

Unemployment and job insecurities in the labour market have become a part of social and economic reality of Europe together with developing disadvantaged groups of population in the labour market. These are characterised by the experience with repetitive or long-term unemployment. They do not have an access to a better job. Growing unemployment have been becoming a commonly solved problem of the EU countries since the 90 s od the last century. The call for a common fight against unemployment was firstly published in 1994 by the European Commission in the document Growth, competitiveness, employment challenges and ways forward for the 21th century (European Commission, 1994).

\section{Iv. Welfare State in Europe}

The European social model is a topic to be discussed amongst experts on social and mainly fiscal policy. Most experts agree that given the changes in the labor market, which resulted in the high unemployment and due to the fiscal crisis of the economy, it is necessary to change the view of the welfare state in Europe. Discussion over the welfare state phenomenon does not concern its existence as such but rather how it should work: to what extent, in what arrangement, and how efficient it should be in the long run (Wildmannová, 2013). All this has an effect on financing and exercises a pressure on the fiscal budgets.

\section{v. The Main Changes Affecting the Transformation of the Welfare State}

The main changes affecting the transformation and requirements of the welfare state are among those:

- International competitors creates pressure to increase labor market flexibility, reduce wages, work and legal protection of employees. In the mid and long run, the European social model is in between these opposite tendencies: on the one hand, there is the pressure of liberalisation, deregulation as a result of globalisation, and on the other hand the EU increases pressure on higher guarantees for social rights and social expenditure increase (Vaughan-Whitehead, 2015)

- Unemployment, especially long term unemployment and insecurity of labour market. People threatened by the unemployment and job insecurity become dependant on social benefits and do not adequately contribute to the social system used to finance the benefits (Keller, 2009).

- Drop in solidarity: drop in solidarity occurs in all areas of the welfare state, some authors (Krebs, 2010, Keller, 2009) speak about its crisis.

- Rising cost trend of the welfare state.

- Last but not the least: demographic changes. Aging population along with other social risks create factors of the social insurance system unsustainability with the old-age pension being the most critical area.

Unemployment, especially long-term unemployment and population aging are significant reasons of changing opinions on the role of the state in the field of social policies. The existing state has been understood as a "generous provider and social policy funder". Currently, the opinions are shifting towards the state transformation guaranteeing social protection and encouraging independent social behaviour (client - provider).

According to the latest OECD data, the social policy expenditure reached $22 \%$ of the GDP in the OECD countries in the year 2012. Traditionally, Europe, led by France with more than $34 \%$ social expenditure to the GDP in the year 2013 ranks amongst the top ones. France, Finland, Belgium, Denmark, Netherland, Italy, Austria, Sweden, and Germany Great Britain currently spend over one fourth of their GDP on social protection expenditure, see Tab. 1.

TABLE I. TOTAL SOCIAL EXPENDITURE AS A PERCENTAGE OF GDP IN THE TIME PERIOD 1995 - 2013

\begin{tabular}{|c|c|c|c|}
\hline \multirow[t]{2}{*}{$\begin{array}{l}\text { Country / } \\
\text { community }\end{array}$} & \multicolumn{3}{|c|}{$\begin{array}{c}\text { Social expenditure as a } \\
\text { share of GDP (in } \\
\text { percentage) }\end{array}$} \\
\hline & 1995 & 2010 & 2013 \\
\hline OECD & . & 21.6 & 21.6 \\
\hline EU 28 & . & 29.4 & 29.5 \\
\hline EUROZONE & . & 30.3 & 30.4 \\
\hline included: & & & \\
\hline Belgium & 27.3 & 30.1 & 30.8 \\
\hline Denmark & 31.9 & 34.7 & 34.6 \\
\hline Finland & 31,4 & 30.6 & 31.2 \\
\hline France & 30.3 & 33.7 & 34.2 \\
\hline Ireland & 18.6 & 29.0 & 32.5 \\
\hline Italy & 24.3 & 29.0 & 30.3 \\
\hline Germany & 28.3 & 30.6 & 29.9 \\
\hline Greece & 22.3 & 29.1 & 31.2 \\
\hline Netherland & 30.6 & 32.1 & 33.3 \\
\hline Portugal & 20.4 & 26.8 & 26.9 \\
\hline Austria & 28.8 & 30.6 & 30.2 \\
\hline United Kingdom & 27.1 & 27.9 & 28.8 \\
\hline Spain & 21.6 & 25.5 & 25.9 \\
\hline Sweden & 33.5 & 30.4 & 30.5 \\
\hline
\end{tabular}

If we focus strictly on the EU and Eurozone countries, Eurostat data indicate the same conclusions as the OECD long-term increase in the social protection expenditure. A rapid increase occurred at the time of the outbreak of the 
financial crisis between 2008 - 2010 which was accompanied by increasing unemployment. A slight increase continued in the following years.

\section{vI. Conclusion}

The current social policy expenditure in the European countries have been kept at a high level for a long time. In most European countries, in particular the western ones, the expenditure exceeds $25 \%$ of the GDP, i.e. more than onefourth of their economies. J. Alber (Albert, 2010) mentions significant heterogeneity of the EU member countries and states that the EU counties are, in terms of the social aspects, to a great extent heterogeneous. One of the reasons for the increased EU heterogeneity is the EU expansion to the east. $\mathrm{He}$ gives an example: the rate of social expenditure in Sweden is $30 \%$ of GDP, whereas in Lithuania only $16 \%$. Europe diverges in social aspects not only because of the economic development of the individual countries but also as a result of various approaches to the social matters. The EU member countries tend to be divided into groups based on the recognition and practicing of a different social expenditure philosophy and this is one of the reasons why the EU fails to achieve a single direction.

Europe keeps struggling with the high unemployment and with the problem of sustainability of the welfare state. People threatened by the unemployment become dependant on social benefits and do not adequately contribute to the social system used to finance the benefits. However, unemployment and job insecurities in the labour market have become a part of social and economic reality of Europe together with the increase of disadvantaged groups of population in the labour market. The social policy is one of the policies which is trying to treat families facing social problems with various social benefits and allowances.

As emphasised by ILO expert, Daniel VaughanWhitehead (Vaughan-Whitehead, 2015), the European social model played a key role in shaping up the European society after the war by encouraging inclusive economic growth, high standard of living and decent working conditions. In some of the European countries the key elements of the European social model have been transformed in response to the crisis that began in 2008. As a result of the crisis it has turned out that the current form of the European social model is not sustainable. The European Commission as well as ILO have come to realize that certain elements of the European social model need to be transformed in light of such challenges such as high unemployment and society aging in Europe.

Therefore, it is presently necessary for the European Union to make a decision crucial to keep the European social model which has played a key role in stabilising economies and maintaining social contract.

\section{Acknowledgment}

The paper resulted from the grant - financial support of the Internal grant agency of the University of Economics, Prague IGS F5/15/2014.

\section{References}

[1] J. Alber, J, "What - if anything - is undermining the European Social Model?", 2010, [online] [cit. 2015-04-27]. Available from Internet: http://www.gbv.de/dms/zbw/632171952.pdf

[2] N. Barr, "The Economics of the Welfare State". Oxford: Oxford University Press, 2004, pp. 7-8.

[3] Z. Baumann, "Work, Consumerism and The New Poor", Oxford: Oxford University Press, 1998

[4] Eurostat. "Expenditure on Social Protection?", 2014, [online] [cit. 2015-010-03]. Available from Internet: http://ec.europa.eu/eurostat/tgm/table.do?tab=1alanguage=enApcode

[5] Eurostat, Pension Expenditure Projections (baseline scenario), 2014, [online] [cit. 2015-010-27]. Available from Internet: http: //ec.europa.eu/eurostat/web/products-datasets/-/tsdde520

[6] European Commission. "Growth, Competitiveness, Employment the Challenges and Ways forward for the 21st Century". Brussel: European Commission, 1994

[7] European Union. "Social Protection Budgets in the Crisis in the EU", 2015, Luxembourg: Publication Office of the EuropeanUnion. [online] [cit. 2015-010-27]. Available from Internet: http://ec.europa.eu/socil/main.jsp?catld=738apubld $\% 7575$

[8] M. Friedman, The Role of Monetary Policy. (Presidential Address, American Economic Association, 29 December 1967). American Economic Review, 58, 1968, č. 1, pp. 1-17.

[9] ILO. "World of Work". Geneva: ILO, 2013

[10] J. Keller, "Twilight of the Welfare State", Prague: Sociological publisher (SLON), 2009, pp. 25 - 28

[11] V. Krebs, et all, "Social Policy”, Prague: Wolters Kluwer. 2015

[12] K. Kubátová, "The role of Government in Solving Problems and the Impact of the Current Crisis”. Prague: Wolters Kluwer, 2011, pp. 3840

[13] L. Musil, "Development of the Welfare State in Europe". Brno: Doplnek Publisher, 1996, pp. $23-24$

[14] OECD. "Social Expenditure Update: Social Spending is Falling in some Countries, but in Many Others it Remains at Historically High Levels" 2014 [online] [cit. 2015-05-27]. Available from Internet: http://www.oecd.org/els/soc/OECD2014-Social-Expenditure-UpdateNov2014-8pages-pdf.

[15] M. Spieker, "The Welfare State and its Crisis". Prague: Czech Christian Academy, 1996, pp. 5 - 8

[16] M. Smutek, “The Welfare State”, Hradec Králové: Gaudeamus, 2005, pp.59-60

[17] D. Vaughan-Whitehead, The European Social Model in Crisis: Is Europe losing its soul?, ILO: Turpin distribution Press, 2015

[18] M. Večeřa, Welfare State. "Theoretical Solutions and Approaches", Praha: Sociological publisher, 2011, pp. 26-28

[19] M. Wildmanová, "What is True for the European Social Model rigor or generosity?" in D. Špalková, L. Matějová, L., "Current Trends in the Public Sector Research". Brno: Masaryk University, 2013, pp. 146-152. 